\title{
Development of learning media based on Lectora Inspire on social science subjects
}

\section{Trisna Ulfatuzzahra}

Sekolah Tinggi Keguruan dan Ilmu Pendidikan (STKIP) PGRI Tulungagung. Jl. Mayor Sujadi No. 7, Kedungwaru, Tulungagung, Jawa Timur 66229, Indonesia. trisnaulfa34@gmail.com

* Corresponding Author

\section{ARTICLE INFO}

\section{Article History}

Received:

4 February 2020;

Revised:

28 February 2020;

Accepted:

26 March 2020

\section{Keywords}

Development; Learning media; Lectora Inspire

\begin{abstract}
The purpose of this research was: 1.) To analyze the needs of the students to the Lectora Inspire learning media; 2.) To produce learning media based on Lectora Inspire; and 3.) Made effective the learning media based on Lectora Inspire. The type of research is Research and Development (R\&D) which refers to the procedural development model that was developed by Borg and Gall, that include research and information collecting, planning, develop a preliminary form of product, preliminary field testing main product revision, main field testing, operational product revision, operational field testing, final product revision, dissemination, and distribution. The result of research development of learning media based on Lectora Inspire on the subjects of social studies, the result of material expert test/content reached the prevalence level $85 \%$, the design expert of media product reached $87,5 \%$, the learning expert reached $92,5 \%$, the field trial result reached $92,83 \%$. Student learning outcomes on average pretest scores were 56,83 , and the posttest score was 83,33 . In the standard t-test with a significance level of 0.05 obtained $t$-count $>$ $\mathrm{t}$-table is $5,09>1,699$, which means $\mathrm{H}_{\mathrm{o}}$ reject and $\mathrm{H}_{\mathrm{a}}$ accepted, so there are significant differences between the student before and after using learning media based on Lectora Inspire. This showed that developed product had qualification of high validity level, so that the learning media was acceptable in learning.
\end{abstract}

This is an open access article under the CC-BY-SA license.

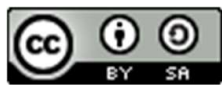

\section{INTRODUCTION}

Education becomes a significant aspect of the creation of quality human resources. Improving the quality of human resources (SDM) should be balanced by increasing the quality of education. Improved educational quality can see from the success of the learning process. The learning process in the education unit organized interactively, inspiring, fun, challenging, motivating learners to participate actively and giving ample space to develop creativity and independence following talents, interests, and physical and psychological development of the student. To realize it, it takes we need the learning media. Shalikah (2017, pp. 9-16) said that learning success is influenced by the completeness of the facilities or media used in the teaching and learning process. The media used, the message or learning material to be delivered should be more varied to optimize students' understanding and encourage students' motivation to learning. It intends because of the variation and diversity of student learning models. For example, in a class, there are several students that some students tend to be able to understand the material using visual media, some students tend to use audio media, and the rest have a kinesthetic learning model. Therefore, teachers must be able to 
combine various types of media in the learning process, combining visual-based media, audio-based media, and kinesthetic-based media so that all students can absorb messages.

Learning media is a tool and material that can use to achieve the learning objectives. Learning Media becomes a liaison between teachers and students, so communication between teachers and students can run effectively. With the media learning, it can encourage students to be more active and communicative in the learning process, so that learning becomes fun, not annoying, and students can easily understand the material presented by the teacher. In this case, teachers should be able to follow the development of science and technology in developing learning media (Ismail, 2017, p. 219). Sukiman (2012) stated that learning media are all things that can use to channel messages from the sender to the recipient. To stimulate the thoughts, feelings, attention, and interests and wishes of students in such a way that the learning process occurs in order to effectively achieve learning objectives (2012, p. 29). Learning media is an essential element in the learning process. The use of instructional media can arouse new desires and interests, arouse motivation and stimulation of learning activities, and even influence students' psychological learning (Arsyad, 2011, pp. 15-16). Based on some of the expert opinions, it can see that learning media is everything that can use to convey messages from teachers to students so that they can arouse desires, interests and stimulate motivation in the learning process to achieve active learning goals (Kusuma, Nasution, \& Anggoro, 2018, p. 191). The benefits of using instructional media are making it easier for teachers to explain concepts that are still abstract and difficult to explain directly to students so that students easily understand the learning material (Umarella, Rahmawati, \& Susilowati, 2018, p. 10). It can present objects that are too big or small into the learning environment, for example, the teacher will show airplanes or bacteria through media images, and can show movements through learning videos (Susilana, 2009, pp. 10-11).

The development of science and technology increasingly encourages renewal in the use of technology in the learning process. Information and communication technology-based learning has changed conventional or traditional learning into media-based learning, including computer and internet media, that gave rise to e-learning (Munir, 2009, p. 3). The rapid development of technology has led to the development of software in learning media, one of which is Lectora Inspire (Nursidik $\&$ Suri, 2018, p. 238) which can use in making interactive and exciting learning media (Haviz, 2013, p. 1). Lectora Inspire based learning media is a learning medium that is easy to use and practical (Astutik \& Rusimamto, 2016, p. 107). Lectora Inspire based learning media have advantages, including lower costs, supporting multimedia content (Shalikhah, 2017, p. 3). This Lectora Inspire based learning media does not require continuous internet access in its use, because the media produced are outputs that can be opened and stored on laptops or computers owned by teachers or students (Tambunan \& Sukarman Purba, 2017, pp. 25-27). The development of Lectora inspire based learning media is made as attractive as possible, so that students are more interested to study in social studies (Kaimuddin, 2014, p. 47).

According to Sholeh Fasthea (2015, p. 4), Lectora Inspires is an authoring tool software for elearning content development developed by Trivantis Corporation. Lectora can be used to create website content or online training courses, e-learning content, educational games, and interactive presentations. It is also possible to convert Microsoft PowerPoint presentations to e-learning content (Hakim \& Haryudo, 2014, p. 15). Lectora Inspire has the advantage that is; it can use to create websites, interactive e-learning content, and product presentations or company profiles (Linda, Erviyenni, Noer, Oktavianti, \& Sellyna, 2016, p. 188). Lectora Inspire makes it very easy for users to create multimedia (audio and video) learning, which can make it easy to create learning media. The template is quite complete, Lectora Inspire provides a media library that is very helpful for users, can convert Microsoft PowerPoint presentations to e-learning content (Rahman, Ismail, \& Nasir, 2014, p. 14). It can publish to various outputs such as HTML5, a single executable file (.exe), CDROM, or e-learning standards such as SCORM and AICC (Fasthea, 2015, p. 4).

The Lectora Inspire program is supported by several features that are very supportive of the compilation of learning media. These features include: 1.) Snagit can create high-resolution computer screenshots, for later use in presentations, documents, and blogs. Snagit is a tool to make it easy to capture screen views and edit them. In other words, the "print screen" revolution; 2.) Camtasia is a software that can use to record work activities that occur on a computer screen, to create a video of 
computer work screen activity. Camtasia functions like video editing software, such as movie maker or Ulead video studio. Besides being able to edit videos, Camtasia is also able to create professional tutorials to capture videos, flash animations, or 3D software quickly. The Flypaper feature has a dual function of being able to make presentations like Microsoft PowerPoint and can also create flash animations at once. Lectora can integrate many files, including flash (with SWF format) (Balai Teknologi Komunikasi Pendidikan Daerah Istimewa Yogyakarta, 2011, p.8).

Problems that arise in the field, when the learning process takes place, students find it challenging to focus on the material delivered by the teacher and are less interested in social studies learning due to several factors. The learning methods that still use the lecture method and are still fixate on textbooks. The textbook used is still an old book so the material presented has not been updated according to technological developments. According to Supardan (2015, p. 17), in the 2013 curriculum for SMP/MTs, it was explained that social sciences is a subject that examines social issues with elements of study in the context of events, facts, concepts, and generalizations. Social studies is a learning program that aims to help and train students, so they can have the ability to recognize and analyze a problem from a variety of perspectives in a comprehensive manner to obtain a more complete and comprehensive picture of something. According to Arsjad (2013, pp. 33-34), the goal of social science education is fundamental that students can develop basic knowledge and skills that are useful for themselves in daily life and can develop an understanding of the development of Indonesian society from the past to the present. Hence, students have pride as Indonesians and love for the motherland.

In line with the above, it is better to use interactive learning media; teachers are not only limited to mastering Microsoft PowerPoint. The researcher made further observations through interviews with social studies teachers of VII grade Dau Malang Junior High School 01. When the learning process takes place, teachers rarely use technology-based learning media because the teacher is limited to operating Microsoft PowerPoint. Other learning media used by teachers in the classroom, namely textbooks and blackboards, so students lack focus on understanding the material delivered by the teacher. Therefore, there is a need for supporting media such as the appearance of images, videos, and edu-cational games to facilitate students in understanding the materials contained in textbooks, and students do not feel bored when studying.

It is necessary to develop learning media that can increase student motivation and encourage students to be more active and communicative in the learning process. Learning media that can be applied are one of the learning media based on Lectora Inspire. Lectora Inspire based learning media is a learning medium that is easy to use and practical. The development of Lectora Inspire based learning media is made as attractive as possible, so that students are more interested and happy to study social studies. The development of Lectora Inspire-based learning media expected to make it easier for students to understand the material in social studies. And then, students are more enthusiastic about studying social studies while providing innovations to students and teachers through the knowledge of advanced technological developments (Shalikhah, 2016, p.102).

Based on the background above, the purpose of this study is to analyze the needs of VII grade students of Dau Malang Junior High School 01 on Lectora Inspire learning media on social studies subjects. Furthermore, the second purpose is to produce Lectora inspire based learning media on IPS subjects, to make effective use of Lectora Inspire based learning media on social studies subjects.

\section{METHOD}

The method used in this research is the research and development method. This research and development methodology is very closely related to the field of learning technology. Learning technology can be defined as the theory and practice of design, development, utilization, management, and evaluation of processes and resources for learning (Setyosari, 2013, p. 228). According to Sukmadinata (2008, pp. 164-165), research and development or research and development is a process or steps to develop a new product or improve existing products, which can account. The development model used in this research development is the Borg and Gall development model through the following steps which can be seen in Figure 1. 
Experiment Design (before-after) O1 X O2 O1 value before treatment and $\mathrm{O} 2$ value after treatment. The trial subjects of the Lectora inspire-based learning media development research are expert lecturers on social content/content, product design expert lecturers and social studies subject teachers of class VII Dau Malang Junior High School 01 as learning experts and users of learning media, namely class VII B students of Dau Malang Junior High School 01. The type used determines the effectiveness of the product in the form of quantitative and qualitative data. Quantitative data information obtained by questionnaire-based and achievement tests. Furthermore, qualitative data in the form of information obtained by interviews and assessment results obtained from the validator.

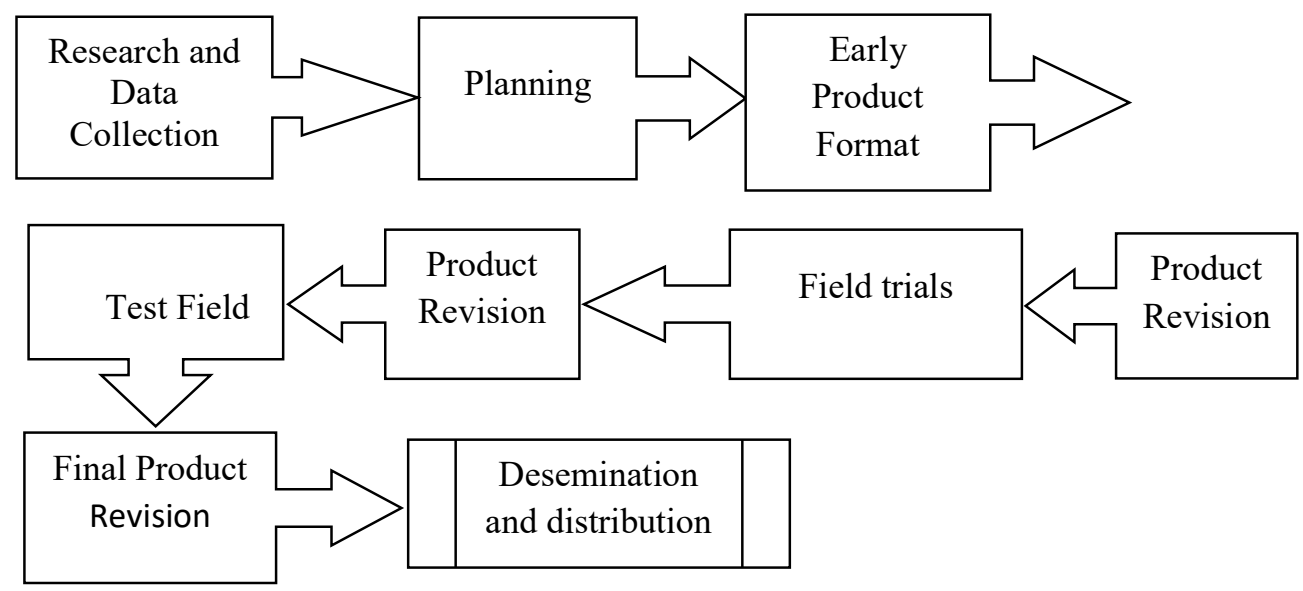

Figure 1. Borg and Gall Development Model

Data collection instruments used were 1.) Questionnaire to obtain data from 3 (three) and students; 2.) Tests, to obtain data about changes that occur in student learning outcomes through pretest and post-test; and 3.) Interview guidelines to find out things from in-depth respondents. Data analysis techniques used are: 1.) Analysis of Learning Content, to formulate the achievement of social studies learning objectives based on Core Competency (IC) and Basic Competency (KD); 2.) Descriptive Analysis, to revise the product development based on Lectora Inspire and to the level of feasibility of the product developed; 3.) Mean (average) analysis, to find out the results of increasing students' understanding before and after using Lectora inspire based learning media development products through mean post-test and mean pre-test; and 4.) T-Test Analysis to determine the effectiveness of the implementation of development products. Value results test analyzed to find out differences after using the product developed in the form of learning media based on Lectora Inspire. The results of the trial were compared with a table of 0.05 , that is, $\mathrm{H} 0=$ there was no significant difference $(5 \%)$ between before and after using the product of the development of learning media based on Lectora Inspire. Furthermore, H1 = there is a significant difference $(5 \%)$ between before and after using Lectora inspire based learning media. From the trial results, a decision will be made, namely, if $\mathrm{t}$-count $>\mathrm{T}$-table, the results are significant, meaning $\mathrm{H} 1$ is accepted, if $\mathrm{t}$-count $<\mathrm{t}$-table, the results are non-significant, meaning H1 reject (Zuhri \& Rizaleni, 2016, p. 113).

\section{FINDINGS AND DISCCUSIONS}

Results

The development of Lectora Inspire based learning media on the theme "Life of Indonesian Communities in the Pre-Literal, Hindu-Buddhist, and Islamic" is an adaptation of the Borg and Gall model. The procedural consist: 1.) Research and data Collection; 2) Planning; 3) Development of initial product format; 4) Initial field trial; 5) Product revision; 6) Field trials; 7) Product revision; 8) Field test; 9) Revisions; and 10) Dissemination and distribution (Syawaluddin, Makkasau, \& Jamal, 2019, p. 109). 


\section{a) Research and Data Collection}

Based on research and data collection through observation and interviews, it was found that social studies learning is still dominant with lectures and focused on textbooks and student worksheets so that it makes students sleepy in class and not concentrated. Besides, the lack of students' ability to read also makes students less enthusiastic about learning (Musa \& Abd Halim, 2015, p. 89). Although schools have facilities such as LCD as a learning tool that supports the use of media. However, it has not been maximally utilized in social studies lessons, because teachers are only limited to being able to operate and use Microsoft PowerPoint presentations, so there is a need for learning media that is suitable for the character of grade VII students at Dau Malang 01 Junior High School. There are materials and videos related to the material so that students easy to understand the material presented and do not experience boredom when learning.

\section{b) Planning}

Planning consists of two stages, namely designing learning material and designing media design. At the material design stage, the first thing to do is to compile core competencies, essential competencies, and learning indicators. Then the material preparation starts with sorting and summarizing the material and taking it from various sources for the pictures and videos included in the material. Next, ask questions that will include in the learning media quiz. Researchers also designed the design of instructional media by making design designs, choosing backgrounds, images, and videos that fit the theme "Life of Indonesian Communities in the Praaksara, Hindu-Buddhist, and Islamic."

\section{c) Development of Initial Product Format}

The development of the initial product format on Lectora inspire based learning media is based on the design that creates at the planning stage.

\section{d) Early Phase Field Trials}

At the initial field trial stage in the form of validation of 3 experts, they got results: a.) Validation of material/content experts, the results of the expert validation of the material/content show the percentage validation rate of $85 \%$. Following the validation scale conversion table, the percentage of the achievement level of $85 \%$ is in a very valid qualification; b.) Validation of product design expert, the results of the validation of the product design expert showed a percentage level of validation of $87.5 \%$. Following the validity scale conversion table, the percentage of achievement level was $87.5 \%$. In a very valid qualification; and c.) Validation of social studies learning experts by social studies teacher, the results of the validation of the learning expert showed that the percentage level of validation was $92.5 \%$. Following the validity scale conversion table, the percentage of achievement level was $92.5 \%$. Are in very valid qualifications. The results of the validation of the assessment by all experts are as follows on Table 1.

Table 1. Expert Assessment Validation Result

\begin{tabular}{clcl}
\hline No. & \multicolumn{1}{c}{ Assessment Validation } & Average & Category \\
\hline 1 & Material Experts/Content & 3.4 & Very Valid \\
2 & Product Design expert & 3.5 & Very Valid \\
3 & Learning Experts IPS & 3.7 & Very Valid \\
\hline
\end{tabular}

\section{e) Product revision}

Furthermore, the learning media development products revise according to the results of criticism and advice from experts.

\section{f) Field trials}


In the field trial stage consists of 10 randomly selected students with a filling poll and interviews with small-class students, thus obtaining quantitative and qualitative data. The results of a small student assessment gained a percentage of $89 \%$ in a highly valid qualification, indicating that the results of the assessment by the small class students state to be very valid and get a good response after using Lectora Inspire-based learning media.

\section{g) Product revision}

After testing for the second time, the product development media-based learning Lectora Inspire was revised again and repaired, including the image of the character of the mobile legend on the Usage instructions page.

\section{8) Field Test}

The revised Lectora Inspire-based learning media development product has teste in the field with 30 large class students of class VII B of Dau Malang 01 Junior High School. The results of the questionnaire assessment of the level of product attractiveness of class students obtained a percentage of $92.83 \%$ are in a very valid qualification. It shows that the results of the assessment by large class students declared very valid and get a good response after using Lectora Inspire based learning media (Yoto \& Wiyono, 2015, p. 211).

Based on the results of the assessment through the implementation of the pretest and posttest given to students before and after using Lectora inspire based learning media, it can be seen that there are differences in values between pretest and posttest.

Table 2. Pretest and Posttest Values

\begin{tabular}{ccc}
\hline Value & Pre-Test & Post-Test \\
\hline Amount & 1705 & 2500 \\
Average & 56.83 & 83.33 \\
\hline
\end{tabular}

Based on the average value of the pretest and posttest results, then the t-test analysis is then performed. The calculation result above shows that $\mathrm{t}$-count $<\mathrm{t}$-table i.e., $5.09<1.699$. Then $\mathrm{H}_{0}$ is rejected, and $\mathrm{H}_{\mathrm{a}}$ is accepted, so there is a significant difference between student grades before and after using Lectora Inspire based learning media. Then from the pre-test mean value, it is known that $\mathrm{X}_{2}$ is greater than $\mathrm{X}_{1}(83.33>56.83)$.

Based on the results of this processing, it can conclude that the learning outcomes (posttest) are significant between before and after using learning media based on Lectora Inspire. In this case, Lectora Inspires based learning media is more effectively used in the social studies learning process compared to conventional teaching media. Thus Lectora Inspire-based learning media has been able to help the ongoing learning activities in achieving learning objectives and play an essential role in encouraging the effectiveness of learning activities.

\section{Discussion}

Research that has done proves that the development of interactive learning media based on Lectora Inspire is very feasible as a learning medium by students. It is in line with research conducted by Trimulyani (2018) on the development of Lectora Inspire application-based learning media in class XI entrepreneurship subjects at Harapan Kartasura Vocational School, Setiono and Agung (2015) on the development of learning media based on Lectora Inspire in the subjects of class XI in Harapan Kartasura Vocational School, Setiono and Agung (2015) on the development of learning media based on Lectora Inspire in the sbject XI basic electrical engineering study at Surabaya Vocational High School 3.

The development of interactive learning media based on Lectora Inspire in social studies subjects is based on an analysis of the need for an attractive learning media not yet available as a support in learning, especially learning media that contains material, practice questions (quiz), educational games and videos related to the material so that can increase student motivation. Lectora 
Inspire-based learning media developed by researchers is an interactive learning media which contains material on theme 4, namely "The Life of Indonesian People in Pre-Literary, HinduBuddhist, and Islamic" which is the second-semester social studies subject material VII and is equipped with pictures and videos related to educational materials and games. In addition, the design theme of "mobile legend," which is used in Lectora Inspire-based learning media, is very compatible with the current character of students so that it can attract students' attention to learning and student motivation to learn in social studies will increase. Lectora inspire based learning media are published with the output of a single executable file (.exe) so that it can be operated on a laptop/computer offline and can be watched by all students in the classroom with the help of LCD and laptop/computer.

Learning by using Lectora Inspire-based learning media that has been developed by researchers, has a positive influence on learning enthusiasm and student learning outcomes. Achievement of the effectiveness of Lectora Inspire-based social learning media is demonstrated by an increase in student learning outcomes before using Lectora inspire-based learning media after using Lectora inspire-based learning media. The improvement in student learning outcomes obtained from the average results of pretest and posttest for VII B students of Dau Malang Junior High School 01 . Based on the results of the pretest and posttest showed a difference, namely the results of the pretest before using Lectora Inspire based learning media obtained an average of 56.83. The posttest acquisition results ie, after using Lectora inspire based learning media, gained several 83.33. Then it can be concluded that there is an increase in student learning outcomes after using Lectora Inspire based learning media. Thus Lectora Inspire-based learning media has been able to help the ongoing learning activities in achieving learning objectives and play an essential role in encouraging the effectiveness of learning activities.

\section{CONCLUSION}

. Based on the process of developing learning media based on Lectora Inspire in social studies subject class VII Dau Malang Junior High School 01, it can conclude several things: 1.) The results of the analysis of teacher and student needs show the results that teachers and students need an interactive learning media based on Lectora Inspire and can increase student learning motivation, so students do not get bored quickly in social studies learning; 2.) The process of developing learning media based on Lectora Inspire in social studies subjects through 10 stages, namely research and initial information collection, planning, development of original product formats, initial trials, product revisions, field trials, product revisions, field trials, revisions final product, dissemination and distribution; and 3.) The effectiveness of the use of learning media based on Lectora Inspire in social studies subjects in class VII Dau Malang Junior High School 01 can be measured in several ways. It through validation by three experts, responses to the assessment of students in the field test as many as 30 people and field tests through pretest and posttest. The results show that $t$-count $>t$-table, which means that $\mathrm{t}$-count is higher than $\mathrm{t}$-table, then $\mathrm{H}_{0}$ is rejected, and $\mathrm{H}_{\mathrm{a}}$ is accepted, so there is a significant difference between students' values before and after using Lectora inspire based learning media. The conclusion of the t-test results is that Lectora Inspire-based learning media is stated to be good and suitable to be used as social studies learning media in class VII Dau Malang Junior High School 01 because it can provide differences in learning outcomes between before and after using Lectora Inspire-based learning media.

\section{REFERENCES}

Arsjad, R. H. (2013). Pendekatan konstektual dalam pembelajaran: Penerapannya pada anak disabilitas belajar. Manado: Penerbit STAIN Manado Press.

Arsyad, A. (2011). Media pembelajaran, Jakarta: Raja Grafindo Persada.

Astutik, M., \& Rusimamto, P. W. (2016). Pengembangan media pembelajaran multimedia interaktif berbantuan software Lectora Inspire untuk meningkatkan hasil belajar pada mata pelajaran teknik listrik di SMK Negeri 2 Surabaya. Jurnal Pendidikan Teknik Elektro, 5(1), 107-114. 
Balai Teknologi Komunikasi Pendidikan Daerah Istimewa Yogyakarta. (2011). Modul pelatihan Lectora Authoring Tool, pengenalan fitur Lectora II Sagit dan Camtasia. Yogyakarta: BTKP DIY.

Fasthea, S. (2015). Merancang desain multimedia pembelajaran interaktif menggunakan software Lectora Inspire. Yogyakarta: Laboratorium Multimedia Pembelajaran Fakultas Ilmu Tarbiyah dan Keguruan UIN Sunan Kalijaga.

Hakim, B. R., \& Haryudo, S. I. (2014). Pengembangan media pembelajaran interaktif animasi flash pada standar kompetensi memasang instalasi penerangan listrik bangunan sederhana di SMK Walisongo 2 Gempol. Jurnal Pendidikan Teknik Elektro, 3(1), 15-21.

Haviz. M. (2013). Research and development: Penelitian di bidang kependidikan yang inovatif, produktif dan bermakna. Ta'dib, 16(1), 1-9. Doi: http://dx.doi.org/10.31958/jt.v16i1.235

Ismail, H. (2017). Pengembangan media pembelajaran menggunakan multimedia interaktif Lectora Inspire pada kompetensi dasar menerapkan macam-macam gerbang dasar rangkaian logika mata pelajaran teknik elektronika dasar di SMK Negeri 2 Surabaya. Jurnal Pendidikan Teknik Elektro, 6(3), 219-223.

Kaimuddin, K. (2014). Implementasi Pendidikan Karakter dalam Kurikulum 2013. Dinamika Ilmu: Jurnal Pendidikan, 14(1), 47-64. Doi: https://doi.org/10.21093/di.v14i1.7

Kusuma, R. D. F. D., Nasution, S. P., \& Anggoro, B. S. (2018). Multimedia pembelajaran matematika interaktif berbasis komputer. Desimal: Jurnal Matematika, 1(2), 191-199. Doi: https://doi.org/10.24042/djm.v1i2.2557

Linda, R., Erviyenni, E., Noer, A. M., Oktavianti, N., \& Sellyna, N. (2016). Development of Lectora Inspire as interactive multimedia chemistry learning in Senior High School. Jurnal Pendidikan Kimia, 8(3), 188-196. Doi: https://doi.org/10.24114/jpkim.v8i3.4537

Munir, M. (2009). Pembelajaran jarak jauh berbasis teknologi informasi dan komunikasi. Bandung: Alfabeta.

Musa, K., \& Abd Halim, H. (2015). Kemahiran interpersonal guru dan hubungan dengan pencapaian akademik pelajar (Interpersonal teacher skill and it's relationship with students' academic achievement). Jurnal Pendidikan Malaysia (Malaysian Journal of Education), 40(2), 89-99. Doi: http://dx.doi.org/10.17576/JPEN-2015-4002-01

Nursidik, H., \& Suri, I. R. A. (2018). Media pembelajaran interaktif berbantu software Lectora Inspire. Desimal: Jurnal Matematika, 1(2), 237-244. Doi: https://doi.org/10.24042/djm.vli2.2583

Rahman, M., Abd., J., Ismail, M. A., \& Nasir, M. (2014). Development and evaluation of the Effectiveness of Computer-Assisted Physics Instruction. International Education Studies, 7(13), 14-22.

Setiono, A., \& Agung, Y. A. (2015). Pengembangan media pembelajaran berbasis Lectora pada mata pelajaran teknik elektronika dasar di SMK Negeri 3 Surabaya. Jurnal Pendidikan Teknik Elektro, 4(3).

Setyosari, P. (2013). Metode penelitian pendidikan dan pengembangan. Jakarta: Kencana Prenadamedia.

Shalikhah, N. D. (2016). Pemanfaatan aplikasi Lectora Inspire sebagai media pembelajaran interaktif. Cakrawala: Jurnal Studi Islam, 11(1), 101-115. Doi: https://doi.org/10.31603/cakrawala.v11i1.105

Shalikhah, N. D. (2017). Media Pembelajaran Interaktif Lectora Inspire Sebagai Inovasi Pembelajaran. Warta LPM, 20(1), 9-16. Doi: https://doi.org/10.23917/warta.v19i3.2842

Sukiman, S. (2012). Pengembangan media pembelajaran. Yogyakarta: Pustaka Insan Madani. 
Sukmadinata, N. S. (2008). Metode penelitian pendidikan. Bandung: Remaja Rosdakarya.

Supardan, D. (2015). Pembelajaran Ilmu Pengetahuan Sosial perspektif filosofi dan kurikulum. Jakarta: Bumi Aksara.

Susilana, R. (2009). Media pembelajaran: Hakikat, pengembangan, pemanfaatan, dan penilaian. Bandung: Wacana Prima.

Syawaluddin, A., Makkasau, A., \& Jamal, I. F. (2019). Pengembangan media pembelajaran berbasis aplikasi Lectora Inspire pada mata pelajaran IPS kelas V Di SDN 197 Sapolohe Kecamatan Bontobahari Kabupaten Bulukumba. JIKAP PGSD: Jurnal Ilmiah Ilmu Kependidikan, 3(3), 109-121. Doi: https://doi.org/10.26858/jkp.v3i3.10236

Tambunan, I. R. S., \& Purba, S. (2017). Pengembangan media pembelajaran berbasis aplikasi Lectora Inspire untuk mata pelajaran dasar dan pengukuran listrik kelas X di SMK Swasta Imelda Medan. Jurnal Manajemen Pendidikan Indonesia, 9(1), 24-34.

Trimulyani, D. (2018). Pengembangan media pembelajaran berbasis aplikasi Lectora Inspire pada mata pelajaran kewirausahaan kelas XI di SMK Harapan Kartasura (Unpublished bachelor thesis). Universitas Muhammadiyah Surakarta, Indonesia.

Umarella, S., Rahmawati, A., \& Susilowati, N. E. (2019, February). Interactive multimedia Lectora Inspire based on problem based learning: Development in the optical equipment. In Journal of Physics: Conference Series (Vol. 1155, No. 1, p. 012011). IOP Publishing.

Wiyono, K. (2015). Pengembangan Multimedia Interaktif Pembelajaran Teori Kinetik Gas Berbantuan Lectora Inspire untuk Siswa Sekolah Menengah Atas (SMA). Jurnal Inovasi dan Pembelajaran Fisika, 2 (2), 211-219.

Yoto, Y., \& Wiyono, K. (2015). Pengembangan multimedia interaktif pembelajaran teori kinetik gas berbantuan Lectora Inspire untuk Siswa Sekolah Menengah Atas (SMA). Jurnal Inovasi Dan Pembelajaran Fisika, 2(2), 211-219. Doi: https://doi.org/10.36706/jipf.v2i2.2626

Zuhri, M. S., \& Rizaleni, E. A. (2016). Pengembangan media Lectora Inspire dengan pendekatan kontekstual pada Siswa SMA kelas X. PYTHAGORAS: Jurnal Program Studi Pendidikan Matematika, 5 (2), 113-119. Doi: http://dx.doi.org/10.33373/pythagoras.v5i2.463 